\title{
CORRECTION
}

\section{Early cervical myelitis after human papilloma virus vaccination}

In the article "Early cervical myelitis after human papilloma virus vaccination" by M. Fernández-Fournier et al. (Neurology ${ }^{\circledR}$ Neuroimmunology \& Neuroinflammation 2014;1:e31-e32), there is an error in the name of the vaccine used, which was in fact the bivalent HPV vaccine with a combined diphtheria/tetanus/pertussis vaccine rather than the quadrivalent HPV vaccine Gardasil, as reported in the article. Accordingly, the authors wish to reword several sentences in the article. Under "Case report," the third sentence should read: "Three days earlier she had received a first dose of bivalent HPV recombinant vaccine together with a combined diphtheria/tetanus/pertussis (DTP) vaccine." In the third paragraph of the Discussion, the first 2 sentences should read: "We present a case of transverse myelitis 3 days after HPV and DTP immunization. To our knowledge, this is the earliest case of CNS inflammation following either HPV or DTP immunization, with a less than 7-day interval from vaccination to symptom onset." Sentence 4 should read: "DTP vaccination might have triggered demyelination; however, CNS demyelination is more frequently associated with HPV vaccination in the medical literature. " The last sentence of the article should read: "However, we must continue to report and investigate cases of inflammatory disorders of the CNS associated with vaccination, both for safety reasons and because it may help comprehend the pathogenesis of subsequent CNS demyelination." The authors regret the errors. 


\section{Neurology \\ Neuroimmunology \& Neuroinflammation}

Early cervical myelitis after human papilloma virus vaccination

Neurol Neuroimmunol Neuroinflamm 2015;2;

DOI 10.1212/NXI.0000000000000064

This information is current as of January 14, 2015

Updated Information \&

Services

Permissions \& Licensing

Reprints including high resolution figures, can be found at:

http://nn.neurology.org/content/2/1/e64.full.html

Information about reproducing this article in parts (figures,tables) or in its entirety can be found online at:

http://nn.neurology.org/misc/about.xhtml\#permissions

Information about ordering reprints can be found online: http://nn.neurology.org/misc/addir.xhtml\#reprintsus

Neurol Neuroimmunol Neuroinflamm is an official journal of the American Academy of Neurology.

Published since April 2014, it is an open-access, online-only, continuous publication journal. Copyright $@$ 2015 American Academy of Neurology. All rights reserved. Online ISSN: 2332-7812.

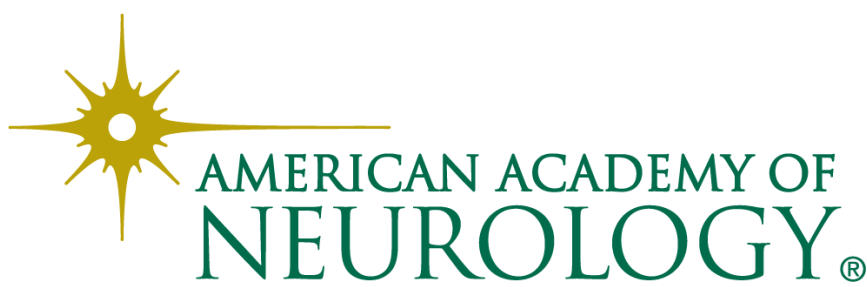

